22. Goadsby PJ, Edvinsson L. Human in vivo evidence for trigeminovascular activation in cluster headache. Brain 1994; 117:427-434.

23. May A, Bahra A, Buchel C, Frackowiak RSJ, Goadsby PJ. Hypothalamic activation in cluster headache attacks. Lancet 1998;351:275-278.

24. May A, Ashburner J, Buchel C, et al. Correlation between structural and functional changes in brain in an idiopathic headache syndrome. Nat Med 1999;5:836-838.

25. Kudrow L. Response of cluster headache attacks to oxygen inhalation. Headache 1981;21:1-4.

26. Friedman AP, Mikropoulos HE. Cluster headache. Neurology 1958;8:653-663.

27. Ibraheem JJ, Paalzow L, Tfelt-Hansen P. Low bioavailability of ergotamine tartrate after oral and rectal administration in migraine sufferers. Br J Clin Pharmacol 1983;16:695-699.

28. Tfelt-Hansen P, Johnson ES. Ergotamine. In: Olesen J, Tfelt-
Hansen P, Welch KMA, eds. The headaches. New York: Raven Press, 1993:313-322.

29. Kitrelle JP, Grouse DS, Seybold ME. Cluster headache: local anesthetic abortive agents. Arch Neurol 1985;42:496-498.

30. Barre F. Cocaine as an abortive agent in cluster headache. Headache 1982;22:69-73.

31. Visser WH, Klein KB, Cox RC, Jones D, Ferrari M. 311C90, a new central and peripherally acting 5 HT-1D receptor agonist in the acute oral treatment of migraine: a double-blind, placebo-controlled dose-range finding study. Neurology 1996; 46:522-526.

32. Rapoport AM, Ramadan NM, Adelman JU, et al. Optimizing the dose of zolmitriptan (Zomig, 311C90) for the acute treatment of migraine. Neurology 1997;49:1210-1218.

33. MaassenVanDenBrink A, Reekers M, Bax WA, Ferrari MD, Saxena PR. Coronary side-effect potential of current and prospective antimigraine drugs. Circulation 1998;98:25-30.

\title{
Neuro/mages
}
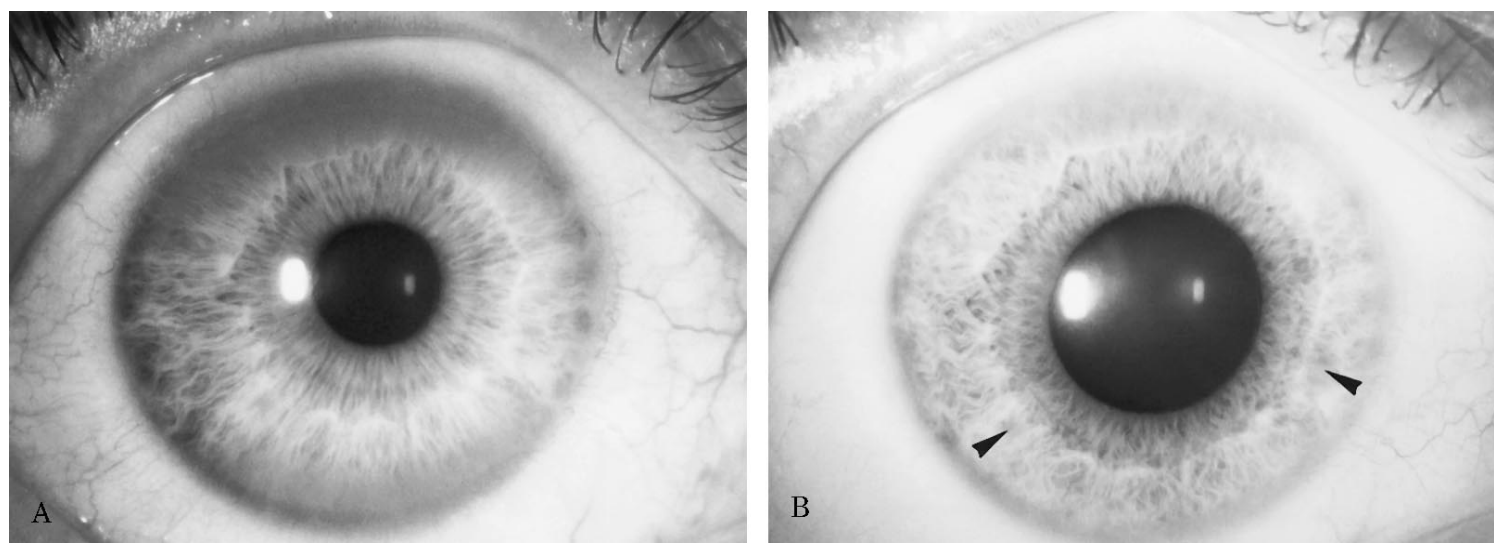

Figure. (A) Marked Kayser-Fleischer corneal ring superiorly and inferiorly. (B) Same eye 12 years after successful treatment with D-penicillamine. Note marked regression of Kayser-Fleischer corneal ring, which has virtually disappeared inferiorly. Note two unrelated small iris nevi of similar color at 4 and 7:30 on the iris (arrowheads).

\section{Kayser-Fleischer corneal ring}

Josef G. Heckmann, MD, PhD, Christoph J.G. Lang, MD, PhD, Bernhard Neundörfer, MD, PhD, Michael Küchle, MD, PhD, Erlangen, Germany

A 26-year-old man was diagnosed with Wilson's disease in 1981. D-penicillamine treatment was started but discontinued because of increased tremor. We first treated the patient in our ICU in 1987 for acute neurologic deterioration after mild brain injury caused by a fall. On admission, he was stuporous and unable to communicate verbally. We observed vertical gaze palsy, an increase in muscle tone, and a prominent circular Kayser-Fleischer corneal ring (A). The laboratory findings revealed low serum copper $(400 \mu \mathrm{g} / \mathrm{L})$, low ceruloplasmin $(7 \mathrm{mg} / \mathrm{dL})$, and elevated $24-$ hour urine copper $(1403 \mu \mathrm{g} / 1800 \mathrm{~mL}$ urine/day). Treat- ment with D-penicillamine was reinstated, along with physiotherapy and ergotherapy. The patient, now 44, is ambulatory and was recently readmitted for follow-up. Mild dysarthria, mild bilateral dysdiadochokinesia, and mildly elevated muscle tone of all four limbs were found, and the Kayser-Fleischer corneal ring had markedly regressed (B). Serum copper (203 $\mu \mathrm{g} / \mathrm{L})$ and ceruloplasmin (3.9 $\mathrm{mg} / \mathrm{dL}$ ) were diminished. D-penicillamine will be continued.

The presence of a Kayser-Fleischer corneal ring ${ }^{1,2}$ may correlate with treatment and markedly regress after successful decoppering.

1. Fleischer B. Zwei weitere Fälle von grünlicher Verfärbung der Hornhaut. Klin Monatsbl Augenheilkd 1903;41:335-352.

2. Finelli PF. Kayser-Fleischer ring: hepatolenticular degeneration (Wilson's disease). Neurology 1995;45:1261-1262. 


\title{
Neurology
}

\author{
Kayser-Fleischer corneal ring \\ Neurology 2000;54;1839 \\ DOI 10.1212/WNL.54.9.1839
}

This information is current as of May 9, 2000

\section{Updated Information \&} Services

Permissions \& Licensing

Reprints including high resolution figures, can be found at: http://n.neurology.org/content/54/9/1839.full

Information about reproducing this article in parts (figures,tables) or in its entirety can be found online at:

http://www.neurology.org/about/about_the_journal\#permissions

Information about ordering reprints can be found online:

http://n.neurology.org/subscribers/advertise

Neurology ${ }^{\circledR}$ is the official journal of the American Academy of Neurology. Published continuously since 1951, it is now a weekly with 48 issues per year. Copyright . All rights reserved. Print ISSN: 0028-3878. Online ISSN: 1526-632X.

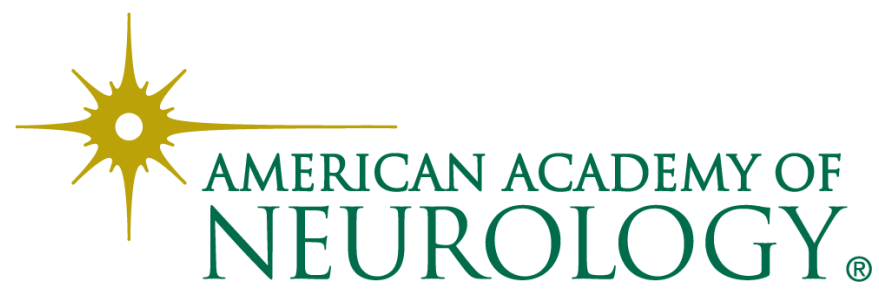

